\title{
Complications of Tyrosine Kinase Inhibitors Therapy in Chronic Myeloid Leukemia - Chronic Phase
}

\author{
DESPINA CALAMAR POPOVICI ${ }^{1,2 \#, ~ I O A N A ~ I O N I T A ~}{ }^{1,3 *}$, MIRELA NEDELCU ${ }^{2}$, CLAUDIU IONITA ${ }^{3,4 \#, ~ H O R T E N S I A ~ I O N I T A ~}{ }^{1}$, \\ RADU DUMITRU MOLERIU ${ }^{5}$, CALIN OVIDIU ILIE ${ }^{6 *}$, DANIELA IACOB ${ }^{7}$, LUCA TUDOR CONSTANTIN ${ }^{8 *}$, ADELINA CHEVERESAN ${ }^{9 *}$, \\ DELIA BERCEANU VADUVA*, DANIELA RADU10 \\ 'University of Medicine and Pharmacy Victor Babes Timisoara, Department of Hematology, 2 Eftimie Murgu Sq., 300041,Timisoara, \\ Romania \\ ${ }^{2}$ City Clinical Emergency Hospital, Hematology Clinic, 1 Hector Str., 300041,Timisoara, Romania \\ 3University of Medicine and Pharmacy Victor Babes Timisoara, Department of Surgery, 2 Eftimie Murgu Sq., 300041,Timisoara, \\ Romania \\ ${ }^{4}$ City Clinical Emergency Hospital, Surgery Clinic,1 Hector Str., 300041, Timisoara, Romania \\ ${ }^{5}$ West University of Timisoara, Faculty of Mathematics and Computer Science, Department of Mathematics, 4 Vasile Parvan Blvd., \\ 300223,Timisoara, Romania \\ EUniversity of Medicine and Pharmacy Victor Babes Timisoara, Faculty of Dental Medicine, Discipline of Dental Technology, \\ 2 Eftimie Murgu Sq., 300041,Timisoara, Romania \\ ZUniversity of Medicine and Pharmacy Victor Babes Timisoara, Department of Neonatology, 2 Eftimie Murgu Sq., 300041,Timisoara, \\ Romania \\ 8University of Medicine and Pharmacy Victor Babes Timisoara, Department of Cardiology, 2 Eftimie Murgu Sq., 300041,Timisoara, \\ Romania \\ 10University of Medicine and Pharmacy Victor Babes Timisoara, Faculty of Medicine, 2 Eftimie Murgu Sq., 300041,Timisoara, \\ Romania \\ 10University of Medicine and Pharmacy Victor Babes Timisoara, Department Surgery, 2 Eftimie Murgu Sq., 300041,Timisoara, \\ Romania
}

Chronic myeloid leukaemia is a malignant tumor of pluripotent haemopoetic stem cell, characterized by increase granulocytes with left shift and the presence of the Ph chromosome.Treatment of chronic phase is made with tyrosine kinase inhibitors administered orally and can have secondary effects: haematological and non-haematological. The purpose of this paper is to assess complications of tyrosine kinase inhibitor therapy in chronic phase of chronic myeloid leukemia and establishing correlations with the type of inhibitor used. The study was performed on a total of 140 patients diagnosed with chronic phase CML in the Hematology Department of the City Clinical Emergency Hospital Timisoara between January 2006 - January 2016. The lot proposed has been studied in terms of anthropometric parameters and also the haematological and biochemical. It showed complications after initiation of therapy with tyrosine kinase inhibitors and also the correlations statistically significant between complications and type of inhibitor used. The study reveals that regardless the type of inhibitor used both haematological complications arise and non haematological. The most common are: neutropenia, thrombocytopenia, anemia, fluid retention, muscle and joint pain. Less common are nausea, diarrhea, abdominal pain, increased liver enzymes. Despite complications of occurring, these modern therapies significantly improve both survival and quality of life of patients.

Keywords: chronic myeloid leukemia, tyrosine kinase inhibitors, treatment, complications

Chronic myeloid leukemia was treated throughout its history with Busulfan or Hydroxyurea and presented a poor prognosis. These agents have controlled hematologic manifestations but have not delayed disease progression. Imatinib, a small molecule tyrosine kinase inhibitor, was first generation of drugs that target BCR-ABL and became the standard first-line therapy in chronic phase of CML.

Subsequently emerged second generation molecules, following the strategies used to overcome resistance to Imatinib. These include new drugs, more powerful like Dasatinib and Nilotinib. These three molecules being surveyed in this paper. The most common side effects of treatment with Imatinib are haematological: neutropenia, thrombocytopenia, anemia, while in the case of Dasatinib most frequent complications are pleural effusion and dyspnea. Nilotinib shows that common side effects neutropenia and thrombocytopenia [1-2].

This paper aims to assess complications of therapy with tyrosine kinase inhibitors in chronic phase of chronic myeloid leukemia and establishing correlations with the type of inhibitor used.

\section{Experimental part}

Material and methods

The study was performed on a total of 140 patients diagnosed with chronic phase CML in the Hematology Department of the City Clinical Emergency Hospital Timisoara between January 2006 - J anuary 2016.

The database includes anthropometric data and results of laboratory investigations, types of inhibitors used and complications occurred after their administration. Data presented in percentage and comparisons between groups were made Oneway Anowa [3-5].

\section{Results and discussions}

The group included a total of 140 patients, of which 57 $(40.72 \%)$ were female and $83(59.28 \%)$ were males. The ratio $B / F$ is 1.45 for male. The age was between 23 and 82 years. The average age was 52.16 years. The patients were divided into three age groups, namely : 20-30 years, 31-50 years and over 50 years. The distribution of patients by age and sex is shown in Table 1. We can see that in the age group 20 to 30 entered a total of 7 patients (5\%), of which

* email: mdioanaionita@yahoo.com, Phone: 0723539800; ctluca@cardiologie.ro,Phone: 0744549340; adedent73@gmail.com; 


\begin{tabular}{|l|l|l|}
\hline Distribution of the lot by age groups & Women & Men \\
\hline $20-30$ years & $3(2.15 \%)$ & $4(2.86 \%)$ \\
\hline $31-50$ years & $15(10.71 \%)$ & $29(20.71 \%)$ \\
\hline Over 50 years & $39(27,86 \%)$ & $50(35.71 \%)$ \\
\hline Total & $\mathbf{5 7 ( 4 0 . 7 2} \%)$ & $\mathbf{8 3 ( 5 9 . 2 8 \% )}$ \\
\hline
\end{tabular}

Table 1

DISTRIBUTION OF THE LOT BY AGE AND GENDER

\begin{tabular}{|c|c|c|c|c|}
\hline Parameter & Values & No. of patients & Percentage & \multirow{31}{*}{$\begin{array}{c}\text { Table } 2 \\
\text { CLINICAL AND LABORATORY PARAMETERS }\end{array}$} \\
\hline \multirow[t]{3}{*}{ Splenomegaly } & $<5 \mathrm{~cm}$ & 65 & 46.43 & \\
\hline & $5-10 \mathrm{~cm}$ & 47 & 33.57 & \\
\hline & $>10 \mathrm{~cm}$ & 28 & 20 & \\
\hline \multirow[t]{3}{*}{ Leukocytes(mmc) } & $<50.000 / \mathrm{mmc}$ & $22.14 \%$ & 31 & \\
\hline & $50-100.000 / \mathrm{mmc}$ & $29.29 \%$ & 41 & \\
\hline & $>100000 / \mathrm{mmc}$ & $48.57 \%$ & 68 & \\
\hline \multirow[t]{3}{*}{$\mathrm{Hb}(\mathrm{g} / \mathrm{dl})$} & $<12 \mathrm{~g} / \mathrm{dL}$ & 48 & 34.29 & \\
\hline & $6-10 / d L$ & 85 & 60.71 & \\
\hline & $<6 \mathrm{~g} / \mathrm{dL}$ & 7 & 5 & \\
\hline \multirow[t]{2}{*}{ Left shift deviation } & Mbl. + Pr. $<20 \%$ & 133 & 95 & \\
\hline & $\mathrm{Mbl} .+\operatorname{Pr} .>20 \%$ & 7 & 5 & \\
\hline \multirow[t]{5}{*}{ Platelets(mmc) } & Normal value & 89 & 63.57 & \\
\hline & Decrease & 6 & 4.29 & \\
\hline & $\begin{array}{l}\text { Increase but } \leq \\
800000 / \mathrm{mmc}\end{array}$ & 29 & 20.71 & \\
\hline & Increase $>800000 / \mathrm{mmc}$ & 7 & 5 & \\
\hline & Increase $\geq 1000000 / \mathrm{mmc}$ & 9 & 6.43 & \\
\hline \multirow[t]{3}{*}{ Basophils in PB. } & $<10 \%$ & 107 & 76.42 & \\
\hline & $10 \%-20 \%$ & 29 & 20.72 & \\
\hline & $>20 \%$ & 4 & 2.86 & \\
\hline \multirow[t]{3}{*}{ Basophils in B.M. } & $<5 \%$ & 91 & 65 & \\
\hline & $5 \%-10 \%$ & 40 & 28.57 & \\
\hline & $>10 \%$ & 9 & 6.43 & \\
\hline \multirow[t]{4}{*}{ Mbl+Promielo in BM. } & $<10 \%$ & 102 & 72.86 & \\
\hline & $10 \%-15 \%$ & 22 & 15.71 & \\
\hline & $16 \%-20 \%$ & 10 & 7.14 & \\
\hline & Peste $20 \%$ & 6 & 4.29 & \\
\hline \multirow[t]{2}{*}{$\mathrm{Cr} . \mathrm{Ph}$} & Present & 120 & 85.71 & \\
\hline & Absent & 20 & 14.29 & \\
\hline \multirow[t]{2}{*}{$\mathrm{BCR}$ - ABL } & Present & 140 & 100 & \\
\hline & Absent & 0 & 0 & \\
\hline
\end{tabular}

\begin{tabular}{|l|l|l|}
\hline Treatment & Frequency (No.of patients) & Percentage \\
\hline IMATINIB & 118 & 84.29 \\
\hline NILOTINIB & 12 & 8.57 \\
\hline DASATINIB & 10 & 7.14 \\
\hline Total & 140 & 100 \\
\hline
\end{tabular}

Table 3

DISTRIBUTION OF PATIENTSBY TYPE OF TREATMENT
3 were women and 4 men, in the group 31 - 50 years we have 44 patients (31.43\%) of which 15 women and 29 men, and 50 years group, 89 patients $(63.57 \%)$ of which 39 were women and 50 were men.

Female gender in the age group over 50 years of age has a number of premenopausal, menopausal disorders that alter daily activities. The increased incidence of malignant pathology in the genital area (uterine cancer, breast) at this age, as well as cardiovascular pathology are more and more common clinical diagnoses [6-15].

There were analyzed few important parameters in clinical and laboratory diagnosis of chronic phase in chronic myeloid leukemia. All the data are shown in Table 2. The distribution of patients according to the type of tyrosine kinase inhibitors used in the treatment of the patients in our study group is shown in Table 3.

The most common complications of patients treated with tyrosine kinase inhibitors were: neutropenia (24\%), anemia (16\%), thrombocytopenia (10\%), fluid retention
(9\%), rash (7\%). Less frequent were: kidney failure $(4 \%)$, joint pain (2.5\%), muscle cramps (2\%), bleeding syndrome (1\%). Distribution of complications in patients diagnosed with chronic myelogenous leukemia-chronic phase is shown in Figurel. Depending on the type of tyrosine kinase inhibitors use, modify complications occur, therefore in the following we present our lot comparative study on those complication [16,17].

To assess complications presented in the Table 4 were performed for all patients complete and extensive biochemical tests, ECG, cardiac ultrasound, and very thorough case history.

The frequency of complications in the studied group is different depending on the type of tyrosine kinase inhibitors used. As seen from the above table for Imatinib, the most common complications were neutropenia, anemia, thrombocytopenia, while for patients treated with Dasatinib the most frequent were hidric retention, chest pain, pulmonary arterial hypertension, heart problems . 


\section{Complications}
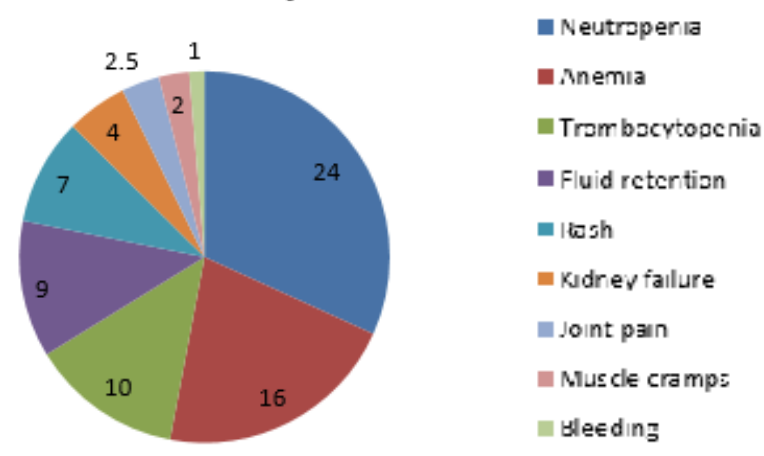

Fig.1Distribution of complications after treatment in CML patients

\begin{tabular}{|l|l|l|l|}
\hline Parameters & IMATINIB (118) & DASATINIB (10) & NILOTINIB (12) \\
\hline Neutropenia & $26(22.03 \%)$ & $4(40 \%)$ & $4(33.33 \%)$ \\
\hline Anemia & $18(15.25 \%)$ & $2(20 \%)$ & $3(25 \%)$ \\
\hline Thrombocytopenia & $8(6.78 \%)$ & $2(20 \%)$ & $4(33.33 \%)$ \\
\hline Fluid retention & $1(0.85 \%)$ & $6(60 \%)$ & $2(16.66 \%)$ \\
\hline Infections & $3(2.54 \%)$ & $2(20 \%)$ & $3(25 \%)$ \\
\hline Bleeding & $1(0.85 \%)$ & $1(10 \%)$ & 0 \\
\hline Rash & $5(4.24 \%)$ & $2(20 \%)$ & $3(25 \%)$ \\
\hline Chest pain & $3(2.54 \%)$ & $8(80 \%)$ & $1(8.33 \%)$ \\
\hline Heart problems & $2(1.69 \%)$ & $7(70 \%)$ & 0 \\
\hline Pulmonary arterial hypertension & 0 & $7(70 \%)$ & $1(8.33 \%)$ \\
\hline Kidney failure & $1(0.85 \%)$ & $2(20 \%)$ & $2(16.66 \%)$ \\
\hline Increased levels of serum lipase & $1(0.85 \%)$ & $1(10 \%)$ & $4(33.33 \%)$ \\
\hline High levels of liver transaminases & $1(0.85 \%)$ & $1(10 \%)$ & $4(33.33 \%)$ \\
\hline High levels of glycemia & $3(2.54 \%)$ & $1(10 \%)$ & $1(8.33 \%)$ \\
\hline QT prolongation & $1(0.85 \%)$ & 0 & 0 \\
\hline Joint pain & $1(0.85 \%)$ & 0 & 0 \\
\hline Muscle cramps & $1(0.85 \%)$ & 0 & 0 \\
\hline
\end{tabular}

Table 4

THE FREQUENCY OF COMPLICATIONSACCORDINGTO THE TYROSINE KINASE INHIBITOR
Regarding patients treated with Nilotinib complications most often occurred were neutropenia, thrombocytopenia, increase of serum transaminases and lipase.

\section{Conclusions}

Patients with chronic myeloid leukemia develop numerous complications that differ depending on the type of tyrosine kinase inhibitor used. What is important to note is that all types of inhibitors occur in a higher percentage of haematological complications as seen in Table 4: Anemia, neutropenia, thrombocytopenia. The importance of these complications has been studied in many clinical trials both in the United States and the UK, and is mainly related to the need to discontinue treatment until normalization of hemogram values [18-20].

This study reveals that depending on the type of tyrosine kinase inhibitors, the most frequently occurring complications vary but there are some haematological changes that persist in a large number of patients regardless of the inhibitor used.

The most common complications of patients with tyrosine kinase inhibitors were: neutropenia (24\%), anemia $(16 \%)$, thrombocytopenia (10\%), fluid retention $(9 \%)$, rash (7\%).

Despite these inconveniences, modern ITK therapy significantly improves both survival and quality of life for patients.

\section{References}

1.IONITA H., Clinical Hematology , Editura Victor Babes, Timisoara, 2015, p. 243 - 261.

2.HOFFBRAND A.V. - P.H.A. Moss, Essential Haematology, $6^{\text {th }}$ edition , 2011, p.191-200.

3.CORTES J., DEININGER M.- Chronic myeloid leukemia, CRC press,2006, p.27- 45.
4.HUGHES T.P., ROSS D.M. and MELO J.V., Handbook of Chronic Myeloid Leukemia, Springer International 2016, p.35 -51.

5.WILLIAMS HEMATOLOGY, $9^{\text {th }}$ Ed, Ed. Mc Graw - Hill Education USA, 2016, p. 1331-1381.

6.PANTEA S., CRAINA M., CHIRIAC V.D., MOLERIU R.D., BOGLUT A., BACEAN MILOICOV O.C., PETRE I., Anatomopathological and Histopathological Aspects of Malignant Tumors of the Uterus, The 13th Conference of the Romanian-German Society of Obstetrics and Gynecology,Timi@oara, Romania, 14-16 September 2017, pag 147 - 150, Ed. Filodiritto Editore Proceeding, ISBN 978-88-95922-959

7.FURAU C., FURAU Gh, TATARU A.L., CRAINA M, PANTEA S., ILYES S.G., BOGLUT A., MOLERIU L.C., PETRE I., Pathology of Postmenopause in Women's Range Arad County, The 13th Conference of the Romanian-German Society of Obstetrics and Gynecology,Timisoara, Romania, 14-16 Sept. 2017, pag 177 - 183, Ed. Filodiritto Editore Proceeding, ISBN 978-88-95922-95-9

8.PANTEA S., DUTA C., SARGAN I., LAZÃR F. PAPURICA F M., BALASAGURAGATA C., BORDOS D. - Histerectomia totalã vaginalã asistatã laparoscopic cu evidare ganglionarã pentru cancer de col incipient tehnicã operatorie. Chirurgia, (2011) 106: 365-368, Nr. 3, Mai - Iunie, ISSN 1221-9118, ISSN on line 184

9.BORDIANU A., FLORESCU I. P., MURESAN A., SARGAN I., The squamous cell carcinoma at the level of the cephalic extremity: epidemiological, clinical and histopathological aspects Romanian Journal Of Morphology And Embryology Volume: 54 Issue: 3 Supplement: Pages: 901-904 Published: 2013

10.BORDIANU A., FLORESCU I. P., MURESAN A., SARGAN I., Anatomoclinical aspects of the basal cell carcinoma at the level of the cephalic end, Romanian Journal Of Morphology And Embryology Volume: 106 Issue: 3 Pages: 609-612 Published: 2011

11.BENGULESCU I., PANTEA S., PANTEA C., SARGAN I, et al. New minimally invasive surgical technique in varicose disease endovenous laser therapy, European J ournal of Medical Research Volume: 15 Supplement: 1 Pages: 228-228 Published: OCT 13, 2010 
12.SALAPA M, POPA Z, MARGAN M, CRAINA M, PANTEA S, ILYES SG, BOGLUT A, PETRE I, False Positive Results in Breast Elastography. A Retrospective Analysis, The 13th Conference of the RomanianGerman Society of Obstetrics and Gynecology,Timi-oara, Romania, 14-16 September 2017, pag 154- 156, Ed. Filodiritto Editore Proceeding, ISBN 978-88-95922-959

13.MURESAN A., LAZAR E., DEMA A., SARGAN I et al. The antigen Ki67: marker of the tumoral proliferation in the invasive mammary cancer and the connection with the classical prognostic factors, Virchows Archiv Volume: 457 Issue: 2 Pages: 168-168 Published: Aug 2010

14.MURESAN A. M., LAZAR E., RAICA M., SARGAN I. et al., HER2 immunoexpression in invasive breast cancer: morpho-clinic and prognostic correlations, Virchows Archiv Volume: 455 Pages: 193 - 193 Published: Aug 2010

15.MURESAN A. M., LAZAR E., RAICA M., SARGAN I. et al., The study of an immunohistochemical aggressivity marker in mammary carcinomas, Virchows Archiv Volume: 455 Pages: 194 - 194 Published: Aug 2010
16.***WINTROBE'S CLINICAL HEMATOLOGY, Thirteenth Edition, Ed.Lippincott Williams \& Wilkins 2014, p.2011 - 2031.

17.BOYIADZIS M., FRAME J., KOHLER D.R. , FOJO T. HematologyOncology Therapy Second Edition, Ed. Mc Graw Hill Education 2015.p.581-607.

18.KESKIN D., ESKAZAN A.E. - The Treatment of Chronic Myeloid Leukaemia (CML) in the Era of Tyrosine Kinase Inhibitors - What is New in the Battle of CML European Oncology \& Haematology, 2015;11(1):30-1.

19. CARELLA A.M., DELLEPIANE C., LOVERA D., IBATICI A., GHIGGI C., CARELLA A., BELTRAMI G., Chronic Myeloid Leukaemia - The Choice of Therapy and Future Perspective European Oncology \& Haematology, 2015;11(1):25-9.

20.CALAMAR POPOVICI, D., IONITA, I., IONITA, C., MARINITA, A., MOLERIU, R.D., IONITA, H., IACOB, D., CHIRIAC, V.D., PETRE, I., Statistical Hierarchy of Diagnostic Criteria for Chronic Myeloid Leukemia, Rev.Chim.(Bucharest), 68, no.10, 2017, p.2463 - 2466,

Manuscript received: 13.01 .2019 